\title{
Blood Transfusion as Regulator of the Immune Response
}

\author{
Leo M.G. van de Watering \\ Sanquin Blood Bank Southwest Region \& Leiden University Medical Center, Leiden, The Netherlands
}

\section{Key Words}

Blood transfusion - Immunoregulation - Transfusion

reaction · Allograft survival · Leukocytes · HLA

\section{Summary}

Immunologically mediated transfusion reactions have always been an important part of transfusion medicine. An additional use for blood transfusions has been investigated for several years now. Blood transfusions were previously predominantly regarded as a 'substrate' for immunologically mediated transfusion reactions, like in hemolytic transfusion reactions, or as a substrate for future immunologically mediated transfusion reactions, like in alloimmunization. Following the reports on the 'blood transfusion effect' on allograft survival, a new role for blood transfusions as immunomodulator or immunosuppressor has been discovered. Different aspects of the immunoregulatory effects of blood transfusions will be discussed.

\section{Introduction}

The immunological effects of blood transfusions have been of major consequence ever since blood was transfused. In the early days of transfusion medicine, hemolytic transfusion reactions made blood transfusions such a high-risk procedure that its use in humans was banned in several countries. When Karl Landsteiner discovered the ABO blood group antigens and their antibodies around 1900, the risk of hemolytic transfusion reactions was greatly reduced, and a major step towards modern transfusion medicine was taken [1]. With the reduced inci-

\section{Schlüsselwörter}

Bluttransfusion - Immunregulation - Transfusionsreaktion · Transplantatüberleben · Leukozyten · HLA

\section{Zusammenfassung}

Immunologisch vermittelte Transfusionsreaktionen haben seit jeher eine wesentliche Rolle in der Transfusionsmedizin gespielt. Bluttransfusionen werden seit einiger Zeit jedoch auch unter einem zusätzlichen Aspekt untersucht: Bluttransfusionen wurden vormals vor allem als "Substrat» immunologisch vermittelter Transfusionsreaktionen angesehen, wie z.B. im Kontext der hämolytischen Transfusionsreaktionen, oder als Träger zukünftiger immunologisch vermittelter Transfusionsreaktionen, wie z.B. der Alloimmunisierung. In der Folge der Beobachtung des so genannten Transfusionseffekts auf das Überleben allogener Transplantate wurde jedoch die Bedeutung von Bluttransfusionen als aktiver Immunmodulator oder Immunsuppressor entdeckt. Die vorliegende Übersichtsarbeit diskutiert einige Aspekte des immunregulatorischen Effekts von Bluttransfusionen.

dence of hemolytic transfusion reactions and the progress made in blood storage and blood banking, more extended surgery was made possible, leading to the present scope of major surgery including resection of malignant tumors, organ transplantation and cardiovascular surgery. The safety of blood transfusions again became a topic of discussion in the early 1980s [2, 3]. The possible deleterious effects of immunomodulation by blood transfusions and the possible transmission of hepatitis viruses and HIV seemed to change a simple trustworthy technique that could save lives into a serious potential killer.

\section{KARGER \\ (C) 2006 S. Karger GmbH, Freiburg \\ Fax +497614520714

Dr. Leo M.G. van de Watering

Sanquin Blood Bank Southwest Region \& Leiden University Medical Center Plesmanlaan 1a, 2333 BZ Leiden, The Netherlands

E-mail leo.vandewatering@bloodrtd.nl 
Table 1. Characteristics of different erythrocyte transfusion products

\begin{tabular}{lcccc}
\hline & Whole blood & $\begin{array}{l}\text { RBC } \\
\text { concentrate }\end{array}$ & $\begin{array}{l}\text { RBC } \\
\text { without buffy coat }\end{array}$ & $\begin{array}{l}\text { RBCs leukocyte- } \\
\text { reduced by filtration }\end{array}$ \\
\hline Erythrocytes, $\mathrm{ml}$ & 210 & 200 & 180 & 160 \\
Hematocrit & 0.42 & 0.60 & 0.59 & 0.57 \\
Leukocytes $\times 10^{9}$ & 3 & 3 & 0.8 & 0.0002 \\
Platelets $\times 10^{9}$ & $>120$ & $>100$ & $<30$ & $<15$ \\
Plasma, ml & 250 & 50 & 25 & 15 \\
\hline
\end{tabular}

Where transfusion medicine was initially hampered by complications related to the transfused erythrocytes, nowadays leukocytes and leukocyte products seem to be responsible for the majority of complications. Repeated transfusion of blood containing allogeneic leukocytes can lead to the formation of alloantibodies. It was already shown in the 1960s that the presence of these antibodies correlated with accelerated allograft rejection [4]. It therefore came as a surprise when Opelz et al. [5] reported that transfused patients had a superior graft survival compared to non-transfused patients. Reducing the leukocytes within the transfused blood by passing the blood over a filter reduced the incidence of alloantibody formation, but also annihilated the positive effect on graft survival [6]. Leukocytes within a blood transfusion therefore seem not only able to activate the immune system, as with alloimmunization, but also to suppress the immune system, as seen with prolonged graft survival. This effect became known as TRIM (transfusion related immunomodulation) [7]. Where immunosuppression can be advantageous in a transplantation setting, it could have detrimental effects in other situations. The possibility of immunosuppression following leukocyte-containing blood transfusions led to several important questions [8]. Would transfusions increase the incidence of post-operative infections? Would they hamper immunosurveillance against cancer cells leading to more cancer recurrence following cancer surgery? What factor is responsible for the immunosuppressive effects? Are cytokines that are produced by the leukocytes during storage responsible, or is it microaggregates that are formed during storage. Or are viable functioning leukocytes needed? All these questions have resulted in many studies investigating various parts of this topic. Some (partial) answers have been found while other questions still remain unanswered.

\section{Transfusion Products}

Over the years, different types of erythrocyte products have been developed, and their use has differed between different countries. To make better usage of a scarce human source and to reduce the incidence of transfusion complications, most countries nowadays split the collected whole blood into different components. With the introduction of splitting the plasma from the red cells and transfusing the concentrated red blood cells (RBCs), a reduction was seen in the occurrence of volume overload. Furthermore, the plasma remained available for further fractionation [9]. The removal of the buffy coat, containing $50-80 \%$ of leukocytes and over $90 \%$ of platelets, from the RBCs led to a reduction in post-transfusion febrile reactions [9]. Also, the buffy coat remained available to prepare platelet concentrates and/or be used in immunological research. To further reduce the incidence of especially HLA (human leukocyte antigen) alloimmunization in poly-transfused and/or transplant patients, filters were developed to selectively reduce the leukocytes in the blood (table 1). This lead to a reduction in the formation of $\alpha$-HLA antibodies in these frequently transfused patients and further reduced the number of febrile complications $[10,11]$. When analyzing the results from different studies across the world, it is important to realize that, although whole blood is not widely used anymore, all other types of erythrocyte products are considered 'the' standard erythrocyte product in some countries. Therefore, there is no 'gold standard' erythrocyte product that can be used as control in all studies.

\section{Direct and Indirect Recognition}

Following allogeneic blood transfusions, the recipient $\mathrm{T}$ cells recognize mismatched HLA molecules on transfused leukocytes as 'non-self'. This direct recognition results in cytokine production (TNF- $\alpha$, IL-1, IL-12) by recipient $\mathrm{T}$ helper (Th) cells, facilitating the proliferation and activation of cytotoxic $\mathrm{T}$ lymphocytes (CTLs) and antibody production by B cells [12]. One of the reasons for introducing changes, such as buffy coat removal or leukocyte reduction by filtration, in the manufacturing process of blood products was to reduce this direct recognition following blood transfusions [10]. Several randomized clinical trials have shown that, with patients requiring prolonged transfusion support, the alloimmunization frequency is indeed the lowest when filtered leukocyte-reduced blood products are used [13-15]. However, for patients who only undergo a single transfusion episode, this clinical advantage of filtered leukocyte-reduced blood products is not yet established [16]. Besides the possible absence of a clinical advantage in these patients because of the lack of recurrent exposure, another explanation may be that far less studies have been performed in these patient groups. 
Following allogeneic blood transfusions, the HLA class II molecules on the recipient antigen-presenting cells (APCs) will bind fragments of transfused alloantigens. These are then presented to recipient CD4+ T-cells which recognize them through their T cell receptor (TCR) and start cytokine production, again facilitating the proliferation and activation of CTLs and antibody production by B cells. This indirect pathway of recognition is less effective than the direct pathway. Nevertheless, it may play a major role in some immunological effects of blood transfusions, like in the transplantation setting [17].

\section{Immunological Transfusion Reactions}

\section{Donor against Patient}

Transfusions containing plasma will also contain antibodies produced by the donor. Donor immunoglobulins directed against recipient leukocytes may cause non-cardiogenic lung edema, or TRALI (transfusion-related acute lung injury), the second most frequent severe transfusion complication. IgG antibodies directed against HLA class I, HLA class II or granulocyte/monocyte antigens have been identified in TRALI [18]. Transfusion of these can result in granulocyte aggregation, activation and microvascular pulmonary injury. With TRALI, by definition, respiratory distress occurs within $6 \mathrm{~h}$ after transfusion of a blood product containing as little as 30 $\mathrm{ml}$ of plasma. With appropriate respiratory intervention, most patients recover within $96 \mathrm{~h}$ of the original insult, without permanent pulmonary sequelae [19].

Strong anti-RBC antibodies (A, B or 'irregular' antibodies) in plasma transfusions can result in severe hemolysis. After multiple minor ABO-incompatible platelet transfusions ( $\mathrm{O}$ to $\mathrm{A}$ or B), the transfused antibodies may produce a positive direct antiglobulin test, but hemolysis seldom occurs. Occasionally, anti-RBC antibodies in intravenous immunoglobulin (IVIG) can cause severe hemolysis.

When transfused immunocompetent donor $\mathrm{T}$ cells proliferate and attack recipient cells, transfusion-associated graft-versushost disease (TA-GVHD) develops. This rare complication is only seen in patients incapable of initiating an effective immune response against the transfused cells, and comes with a mortality rate of over $90 \%$ [20, 21]. Besides immunocompromised patients, other risk factors include the use of relatives as donor, HLA-homozygous donors and fresh (whole) blood containing viable lymphocytes [22, 23]. The chance of an HLA-homozygous blood product, haploidentical with the recipient, is approximately $1: 800$, but only a small minority of these transfusions actually cause TA-GVHD. Since in AIDS patients, TA-GVHD seldom occurs, there may be an additional role for T cell help by recipient CD4 cells [24].

\section{Patient against Donor}

Patients may, as a result of previous transfusions or pregnancies, have developed antibodies directed against components of the transfused blood. Antibodies against transfused cellular components will result in accelerated destruction/removal of these transfused cells. Destruction of erythrocytes by anti$\mathrm{ABO}$ or anti-Rh-D is nowadays seldom seen and most often the result of clerical or clinical errors [25]. Antibodies against other, 'irregular', antigens are found in $1-2 \%$ of unselected hospital patients, and are highly dependent on the number of previously received blood transfusions. $3-8 \%$ of patients will make new or additional antibodies against erythrocytes following a single transfusion episode [16, 26-28]. There is no standard time course of the titers of these new antibodies. They differ with the different type of antibodies and with the use of different detection techniques. Some are rapidly detected and become undetectable after only a few weeks while other antibodies take longer to become detectable but remain detectable for a longer period of time [29, 30]. This means that the specificities of antibodies that are found following transfusions partly depend on the time interval between transfusion and testing, and the test technique used [31]. As memory cells still remain after antibodies have been formed and later declined to undetectable levels, a following exposure to the antigen will result in rapid antibody production, eventually leading to a delayed hemolytic transfusion reaction [32]. Following 20 transfusions, the prevalence of antibodies against erythrocytes will have been increased to around $10 \%$ of patients, stabilizing at $\pm 30 \%$ of patients following more than 100 transfusions [33]. The most important of the 'irregular' antigens, based on immunodominance and antigen frequency, are c, E and Kell. The preventive matching for c, E, and Kell in patients requiring chronic transfusion support will reduce broad red cell alloimmunization.

HLA antibodies, granulocyte antibodies, or a combination of both can cause the destruction of transfused leukocytes. This destruction may result in febrile non-hemolytic transfusion reactions (FNHTR). As leukocytes are only contaminants in most transfusion products, different techniques have been developed to reduce the leukocyte content of blood transfusions. Following the introduction of buffy coat removal, a decline in the incidence of FNHTR was seen [9]. Further reduction of the leukocyte content by filtration also further reduced the incidence of FNHTR [10,11].

Antibodies against platelets may seriously reduce the life span of transfused platelets and eventually result in refractoriness to random donor platelets $[34,35]$. HLA antibodies are most frequently involved in immunological refractoriness. Especially multi-specific HLA antibodies are associated with lack of increment [36]. In a minority of patients, HLA antibodies will disappear despite ongoing transfusion therapy. Occasionally, HPA antibodies can cause platelet refractoriness. These are nearly always found in combination with HLA antibodies [37]. The most frequently involved antigens are HPA-1a and HPA-5b. HPA antigens need processing and presentation by recipient APCs before antibody formation can be induced. As not all HLA class II molecules present HPA-1a and HPA-5b 
equally effectively, antibody responders to HPA are often restricted to specific HLA subtypes (HPA-1a with DR52a, HPA5b with DRw6) [38]. An additional rare transfusion complication, especially correlated with HPA-1a antibodies, is post-transfusion purpura (PTP). PTP occurs around 9 days (range 1-24 days) after a transfusion with whole blood, RBCs or platelets, and is mainly seen in women with previous pregnancies. They suffer bleeding and extreme thrombocytopenia as a result of autologous platelet destruction. Paradoxically, PTP patients are negative for the antigen against which the antibodies are directed. The precise mechanism is not understood, but following blood transfusion, recipient platelets may transiently express donor-derived antigens. ABO antibodies do very rarely cause platelet refractoriness, although a $10-20 \%$ reduced recovery of platelets can be seen with high titers [39].

Antibodies directed against non-cellular transfusion components may also result in transfusion reactions. Skin reactions are often related to $\mathrm{IgE}$ antibodies while $\mathrm{IgG}$ antibodies against plasma proteins, such as IgA or Chido/Rodgers, may result in severe hypotension and respiratory distress [40-42].

\section{Mechanisms of Immunomodulation}

Different mechanisms may be involved in the immunological effects of blood transfusions: i) the transfusion of soluble HLA class I peptides, donor immunoglobulins and other modulatory constituents of allogeneic plasma [43-47], ii) the transfusion of response modifiers, such as histamine, myeloperoxidase and soluble Fas ligand, produced and/or released during extracorporeal storage [43, 48-50], and iii) the transfusion of immunologically active allogeneic leukocytes that interact with recipient cells [51-53]. These 3 mechanisms may all play various roles in different immunomodulatory effects of blood transfusions. We will focus on the effects of blood transfusions on transplant survival, post-operative infections and cancer recurrence.

\section{Transplant Survival}

The initial report on the beneficial effect of blood transfusions on graft survival was published in 1973 by Opelz et al. [5]. Notwithstanding the progress made in immunosuppressive drugs and histocompatibility matching since then, the effect can still be demonstrated [54]. Important observations concerning the underlying mechanism were made by Persijn et al. [6] who showed that a single transfusion could suffice as long as it was not leukocyte-depleted by filtration, and by Lagaaij et al. [55] who showed a crucial role for HLA-DR matching of the blood transfusion with the recipient. Over the years, mechanisms like donor selection, anergy and apoptosis have been suggested for this 'blood transfusion effect':
- Donor selection: Selection of a cross-match-negative donor in poly-transfused patients will preferentially select donors against whom a patient cannot easily respond [56].

- Anergy: Donor APCs lose costimulatory molecules during storage. Following transfusion, these impaired APCs cannot supply the costimulatory signal to the recipient $\mathrm{T}$ cells which will then become anergic instead of activated [57].

- Apoptosis: During storage, soluble HLA, Fas and other modulators accumulate in the donor blood. Following transfusion, these molecules bind to recipient $\mathrm{T}$ cells leading to apoptosis instead of activation [58].

If the above suggested mechanisms do not explain the importance of sharing 1 HLA-DR between blood donor and recipient, the following suggestion does: regulatory T cells $[59,60]$. What special circumstances occur when blood donor and recipient share 1 HLA-DR? Following the blood transfusion, donor APCs carrying both mismatched HLA and matched HLA-DR containing donor-specific peptides can induce a strong immune response. Part of the induced recipient T cells will be directed against 'matched HLA-DR containing donorspecific peptides' (fig. 1b). If the donor subsequently donated an organ for transplantation, a special situation arises. The $\mathrm{T}$ cells that, by direct recognition, do react with the graft will become activated, and start expressing HLA class II molecules. Part of their HLA-DR molecules will contain donorspecific peptides. As a result, the transfusion-induced recipient $\mathrm{T}$ cells will recognize, as their specific target, these cells now expressing 'matched HLA-DR containing donor-specific peptides'. They will thereby down-regulate this, by direct recognition initiated, reaction against the graft (fig. 1c) [61, 62]. The indirect recognition of the graft will also be reduced. In indirect recognition, the recipient APCs present donorspecific peptides in HLA class II. In a normal situation, recipient Th cells may recognize these and start cytokine production, thereby facilitating the proliferation and activation of CTLs and antibody production by B cells. In this situation, the transfusion-induced $\mathrm{T}$ cells will recognize the recipient APCs presenting 'matched HLA-DR containing donorspecific peptides' as their specific target. These T cells will thereby also reduce the effect of indirect recognition, which will further down-regulate the immune response against the transplanted organ (fig. 1c).

There are 2 key points in this suggested mechanism: i) the sharing of one HLA-DR between blood donor and recipient, facilitating the induction of the recipient $\mathrm{T}$ cells directed against 'matched HLA-DR containing donor-specific peptides' that will control a future reaction, and ii) the sharing of donor-specific peptide(s) between blood donor and organ donor, which are not shared with the recipient. These donorspecific peptides may consist of fragments of HLA class I molecules or from any other polymorphic protein. This mechanism can therefore also explain prolonged graft survival in patients where the blood donor and the organ donor were not the same person and did not share HLA antigens [60]. 
Fig. 1. Cellular interactions following blood transfusions and/or transplantation. a Transplantation without previous blood transfusion.

1. By direct recognition activated $\mathrm{T}$ cells start expressing HLA class II. 2. Donorspecific peptides are released. 3. Recipient APCs present donorspecific peptides in HLA class II for indirect recognition. b Blood transfusion sharing one HLA-DR. A blood transfusion, sharing one HLA-DR, induces different $T$ cells in the recipient. Part of these T cells will recognize the shared HLA-DR with donor-specific peptide. c Transplantation after an HLA-DR-shared blood transfusion. 1. By direct recognition activated $\mathrm{T}$ cells start expressing HLA class II. 2. Donorspecific peptides are released. 3. Recipient APCs present donorspecific peptides in HLA class II for indirect recognition. 4 . The $\mathrm{T}$ cells induced by transfusion will recognize APCs and activated $\mathrm{T}$ cells as specific target.

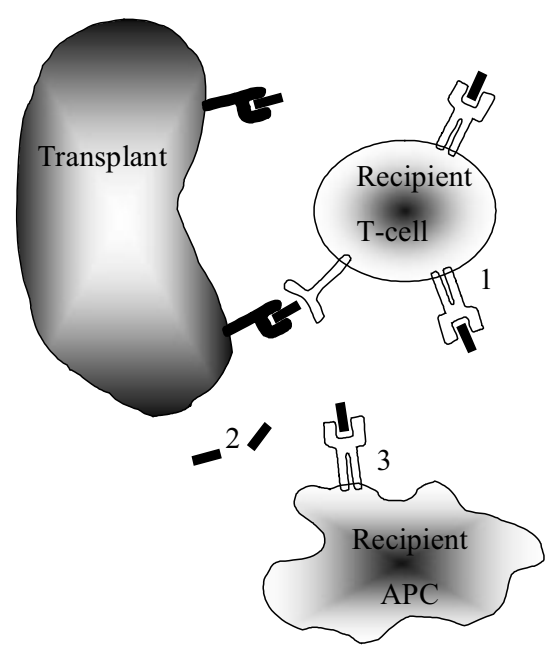

Structures:

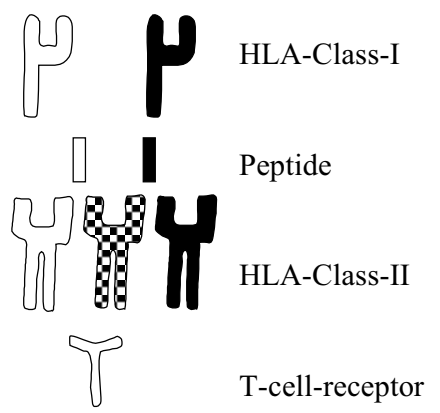

Filling:
Recipient
Donor
$\otimes$ Shared: Donor - Recipient

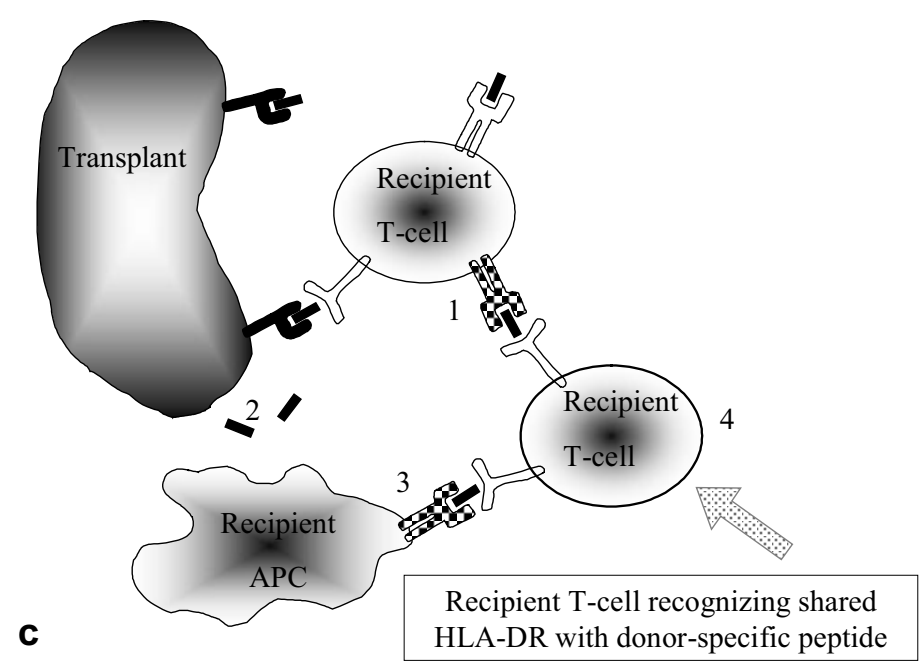




\section{Postoperative Infections}

The effect of blood transfusions on the incidence of postoperative infections is widely researched [53, 63-70]. Of the possible underlying mechanisms, the effects of cellular components are the most extensively investigated in the perioperative setting, especially in abdominal surgery and cardiac surgery. Here, the shift towards a Th2 type of immune response by blood transfusions is superimposed on the shift in Th response associated with trauma and surgery. This induces impairment of monocyte and natural killer (NK) cell functions with reduced phagocytosis, reduced killing of microorganisms and an absent pro-inflammatory response to bacterial endotoxins as lipopolysaccharide (LPS) [71, 72]. The randomized controlled trials investigating postoperative infections within patient groups receiving blood products differing in leukocyte content, produced results that, at first glance, were contradictory $[53,66,68,73-77]$. Part of this was based on the lack of a uniform definition to establish postoperative infections, making especially multi-center studies prone to confounding. Different studies showed effects ranging from transfusions having absolutely no effect, to transfusions being the number-one predictor of postoperative infections. More precise analyses of the data seems to suggest the existence of a threshold for the total number of leukocytes being transfused in a single transfusion event of about $3 \times 10^{9}$, above which an increase in postoperative infections may be seen. In studies comparing whole blood or plasma-reduced RBC transfusions with transfusions leukocyte-reduced by filtration, significant differences were found even after just 1 single transfusion [71,74]. In studies comparing buffy coat-depleted RBCs with transfusions leukocyte-reduced by filtration, significant differences can be found in the subgroup of patients receiving more than 2-4 units of blood, depending on the efficacy of the buffy coat removal $[53,73,77]$. In some studies comparing buffy-coat depleted RBCs with transfusions leukocyte-reduced by filtration, the majority of patients in the non-filtered trial arm did not receive enough transfusions to reach the threshold, resulting in non-significant differences between the trial arms [75]. The ongoing trend to minimize the number of perioperative blood transfusions will increase the number of patients needed within a transfusion study to reach statistically sound conclusions. With the introduction of universal leukocyte reduction by filtration for all erythrocyte transfusions, reductions in febrile reactions and the use of antibiotics have been reported, while a reduction in serious infectious complications is seldom observed [78-80]. This lack of effect may be based on the unselected patient population analyzed in the before/after studies [81]. These include large groups of patients undergoing types of surgery for which a beneficial effect has never been shown or was never investigated.

\section{Cancer Recurrence}

After more than 2 decades of research into this matter, there is still no strong evidence that there is a deleterious effect of blood transfusions on cancer recurrence [2, 82-85]. Only 1 randomized clinical trial on the effect of leukocyte reduction on cancer recurrence was published [85]. It showed no difference in cancer recurrence between the transfusion of filtered RBCs and buffy coat-depleted RBCs. The discussion on a possible effect of blood transfusions on cancer recurrence was started by Gantt's question in 1981 [2] which is substantiated by the following observations:

- Immunosurveillance against cancer may occur [86].

- Blood transfusions can result in immunosuppression, as shown with prolonged graft survival [5]. Other reported immunosuppressive effects of blood transfusions are decreased NK cell numbers and activity, decreased phagocytotic activity and decreased delayed-type hypersensitivity response [87]. Patients with prolonged immunosuppression show an increased incidence of malignancies [88]. Some of these patients show a response against the tumor on reduction or cessation of the immunosuppressive therapy [89].

- Animal studies show an increase in tumor growth following allogeneic blood transfusions [90, 91].

However, the following points may explain the lack of proof from the clinical studies:

- Not all blood transfusions result in immunosuppression and prolonged graft survival. Only if 1 HLA DR antigen is shared, a graft survival-prolonging immunosuppressive effect will be observed [55]. This is seldom verified within the transfusion studies.

- In mice, post-transfusion chimerism remains far longer detectable than in humans. This suggests different mechanisms in 'clearing' allogeneic cells and could limit the conclusions that can be drawn from transfusion research in these animals $[92,93]$.

- Patients on immunosuppressive therapy show only an increase in the incidence of specific malignancies, such as lymphomas, where most studies are performed in patients with other types of malignancy [89].

- The majority of malignancies do not elicit an immune response [94]. With the malignancies that do have this possibility, tumor cells often show escape mechanisms, such as down-regulation of HLA class I expression, or reduced production/increased degradation of involved antigens [ $[95$, 96]. This will result in the selective outgrow of tumor cells that are not hampered by the immune response. With these malignancies, immunosurveillance can therefore only play an important role in the early (preclinical) phases of the disease. As all studies analyzed patients with an established malignancy, the tumors had already passed the phase where an immune response could eradicate all tumor cells. 
In summary, concerning the putative effect of blood transfusions on cancer recurrence, it can be said that not all transfusions are tolerance-inducing, only few malignancies are immunogenic, and if immunosurveillance against a specific tumor does exist and some blood transfusions can suppress this immunosurveillance, blood transfusions during surgery come in such a late phase of the disease that immunosurveillance has already had its chance and failed.

\section{References}

1 Landsteiner K: Über Agglutinationserscheinungen normalen menschlichen Blutes. Wien Klin Wochen schr 1901;14:1132.

2 Gantt CL: Red blood cells for cancer patients. Lancet 1981;ii:363.

3 Joint statement on acquired immune deficiency syndrome (AIDS) related to transfusion. Transfusion 1983;23:87-8.

4 Kissmeyer-Nielsen F, Olsen S, Petersen VP, Fjeld borg O: Hyperacute rejection of kidney allografts, associated with pre-existing humoral antibodies against donor cells. Lancet 1966;ii:662-665.

$\checkmark 5$ Opelz G, Sengar DP, Mickey MR, Terasaki PI: Effect of blood transfusions on subsequent kidney transplants. Transplant Proc 1973;5:253-9.

6 Persijn GG, Cohen B, Lansbergen Q, van Rood JJ: Retrospective and prospective studies on the effect of blood transfusions in renal transplantation in The Netherlands. Transplantation 1979;28:396-401.

7 Vamvakas EC, Blajchman MA: Deleterious clinical effects of transfusion-associated immunomodulation: fact or fiction? Blood 2001;97:1180-95.

$>8$ Blajchman MA: Transfusion immunomodulation or TRIM: What does it mean clinically? Hematology 2005;10(suppl 1):208-214.

$\checkmark$ Chaplin H Jr: Packed red blood cells. N Engl J Med 1969;281:364-7.

10 Diepenhorst P, Engelfriet CP: Removal of leukocytes from whole blood and erythrocyte suspensions by filtration through cotton wool. V. Results after transfusion of 1,820 units of filtered erythrocytes. Vox Sang 1975;29:15-22.

11 Ibojie J, Greiss MA, Urbaniak SJ: Limited efficacy of universal leucodepletion in reducing the incidence of febrile nonhaemolytic reactions in red cell transfusions. Transfus Med 2002;12:181-185.

12 Fast LD: Recipient elimination of allogeneic lymphoid cells: donor CD4(+) cells are effective alloantigen-presenting cells. Blood 2000;96:1144-1149.

13 Novotny VM, van Doorn R, Witvliet MD, Claas FH, Brand A: Occurrence of allogeneic HLA and non-HLA antibodies after transfusion of prestorage filtered platelets and red blood cells: a prospective study. Blood 1995;85:1736-1741.

14 Scornik JC, Ireland JE, Howard RJ, Fennell RS3, Pfaff WW: Role of regular and leukocyte-free blood transfusions in the generation of broad sensitization. Transplantation 1984;38:594-598.

15 van Marwijk Kooy M, van Prooijen HC, Moes M, Bosma-Stants I, Akkerman JW: Use of leukocytedepleted platelet concentrates for the prevention of refractoriness and primary HLA alloimmunization: a prospective, randomized trial. Blood 1991;77:201205.

16 van de Watering L, Hermans J, Witvliet M, Versteegh M, Brand A: HLA and RBC immunization after filtered and buffy coat-depleted blood transfusion in cardiac surgery: a randomized controlled trial. Transfusion 2003;43:765-771.

17 Liu Z, Braunstein NS, Suciu-Foca N: T cell recognition of allopeptides in context of syngeneic MHC. J Immunol 1992;148:35-40.
18 Kleinman S, Caulfield T, Chan P, Davenport R, McFarland J, McPhedran S, Meade M, Morrison D, Pinsent T, Robillard P, Slinger P: Toward an understanding of transfusion-related acute lung injury: statement of a consensus panel. Transfusion 2004; 44:1774-1789.

19 Popovsky MA: Transfusion-related acute lung injury. Curr Opin Hematol 2000;7:402-7.

20 Aoun E, Shamseddine A, Chehal A, Obeid M, Taher A: Transfusion-associated GVHD: 10 years' experience at the American University of BeirutMedical Center. Transfusion 2003:43:1672-1676.

21 Spector D: Transfusion-associated graft-versus-host disease: an overview and two case reports. Oncol Nurs Forum 1995;22:97-101.

22 Ohto H, Anderson KC: Survey of transfusion-associated graft-versus-host disease in immunocompetent recipients. Transfus Med Rev 1996;10:31-43.

23 Arsura EL, Bertelle A, Minkowitz S, Cunningham JN Jr, Grob D: Transfusion-associated-graft-vs-host disease in a presumed immunocompetent patient. Arch Intern Med 1988;148:1941-1944.

24 Kruskall MS, Lee TH, Assmann SF, Laycock M, Kalish LA, Lederman MM, Busch MP: Survival of transfused donor white blood cells in HIV-infected recipients. Blood 2001;98:272-9.

25 Stainsby D, Russell J, Cohen H, Lilleyman J: Reducing adverse events in blood transfusion. $\mathrm{Br} \mathrm{J}$ Haematol 2005;131:8-12.

26 Ness PM, Shirey RS, Thoman SK, Buck SA: The differentiation of delayed serologic and delayed hemolytic transfusion reactions: incidence, longterm serologic findings, and clinical significance. Transfusion 1990;30:688-693.

27 Redman M, Regan F, Contreras M: A prospective study of the incidence of red cell allo-immunisation following transfusion. Vox Sang 1996;71:216-220.

28 Fluit CR, Kunst VA, Drenthe-Schonk AM: Incidence of red cell antibodies after multiple blood transfusion. Transfusion 1990;30:532-535.

29 Ramsey G, Larson P: Loss of red cell alloantibodies over time. Transfusion 1988;28:162-165.

30 Schonewille H, Haak HL, van Zijl AM: RBC antibody persistence. Transfusion 2000;40:1127-1131.

31 Schonewille H, Haak HL, van Zijl AM: Alloimmunization after blood transfusion in patients with hematologic and oncologic diseases. Transfusion 1999:39:763-71.

32 Issitt PD, Anstee DJ: Applied Blood Group Serology, 4th ed. Durham, NC, Montgomery Scientific Publications, 1998.

33 Spanos T, Karageorga M, Ladis V, Peristeri J, Hatziliami A, Kattamis C: Red cell alloantibodie in patients with thalassemia. Vox Sang 1990;58:5055.

34 Murphy MF, Waters AH: Platelet transfusions: the problem of refractoriness. Blood Rev 1990;4:16-24.

35 Novotny VM: Platelet transfusion refractorinessprevention and therapeutical approaches. Transfus Clin Biol 1995;2:47-49.
6 Vamvakas EC: Meta-analysis of randomized controlled trials of the efficacy of white cell reduction in preventing HLA-alloimmunization and refractoriness to random-donor platelet transfusions. Transfus Med Rev 1998;12:258-270.

37 Schnaidt M, Northoff H, Wernet D: Frequency and specificity of platelet-specific alloantibodies in HLA-immunized haematologic-oncologic patients. Transfus Med 1996; 6:111-114.

38 Mueller-Eckhardt C, Kiefel V, Kroll H, MuellerEckhardt G: HLA-DRw6, a new immune response marker for immunization against the platelet alloantigen Bra. Vox Sang 1989;57:90-91.

39 Lee EJ, Schiffer CA: ABO compatibility can influence the results of platelet transfusion. Results of a randomized trial. Transfusion 1989;29:384-389.

40 Sandler SG, Mallory D, Malamut D, Eckrich R IgA anaphylactic transfusion reactions. Transfus Med Rev 1995;9:1-8.

41 Wilhelm D, Kluter H, Klouche M, Kirchner H: Impact of allergy screening for blood donors: relationship to nonhemolytic transfusion reactions. Vox Sang 1995;69:217-221

42 Lambin P, Le Pennec PY, Hauptmann G, Desaint O, Habibi B, Salmon C: Adverse transfusion reactions associated with a precipitating anti-C4 antibody of anti-Rodgers specificity. Vox Sang 1984;47: 242-249.

43 Ghio M, Contini P, Mazzei C, Brenci S, Barberis G, Filaci G, Indiveri F, Puppo F: Soluble HLA class I, HLA class II, and Fas ligand in blood components: a possible key to explain the immunomodulatory effects of allogeneic blood transfusions. Blood 1999;93:1770-7.

44 Horimi T, Terasaki PI, Chia D, Sasaki N: Factors influencing the paradoxical effect of transfusions on kidney transplants. Transplantation 1983;35:320 323.

45 Blumberg N, Heal JM, Murphy P, Agarwal MM, Chuang C: Association between transfusion of whole blood and recurrence of cancer. Br Med J (Clin Res Ed) 1986;293:530-533.

46 Magee CC, Sayegh MH: Peptide-mediated immunosuppression. Curr Opin Immunol 1997;9:669675.

47 Marsh J, Donnan PT, Hamer-Hodges DW: Association between transfusion with plasma and the recurrence of colorectal carcinoma. Br J Surg 1990; 77:623-626.

48 Nielsen HJ: Detrimental effects of perioperative blood transfusion. Br J Surg 1995;82:582-7.

49 Mynster T, Nielsen HJ: The impact of storage time of transfused blood on postoperative infectious complications in rectal cancer surgery. Danish RANX05 Colorectal Cancer Study Group. Scand J Gastroenterol 2000;35:212-7.

50 Vamvakas EC, Blajchman MA: Prestorage versus poststorage white cell reduction for the prevention of the deleterious immunomodulatory effects of allogeneic blood transfusion. Transfus Med Rev 2000;14:23-33. 
51 Gafter U, Kalechman Y, Sredni B: Blood transfusion enhances production of T-helper-2 cytokines and transforming growth factor beta in humans. Clin Sci (Lond) 1996;91:519-523.

52 Heiss MM, Fraunberger P, Delanoff C, Stets R, Allgayer H, Strohlein MA, Tarabichi A, Faist E, Jauch KW, Schildberg FW: Modulation of immune response by blood transfusion: evidence for a differential effect of allogeneic and autologous blood in colorectal cancer surgery. Shock 1997;8:402-8.

53 van de Watering LM, Hermans J, Houbiers JG, van den Broek PJ, Bouter H, Boer F, Harvey MS, Huysmans HA, Brand A: Beneficial effects of leukocyte depletion of transfused blood on postoperative complications in patients undergoing cardiac surgery: a randomized clinical trial. Circulation 1998;97:562-568.

54 Opelz G, Vanrenterghem Y, Kirste G, Gray DW, Horsburgh T, Lachance JG, Largiader F, Lange H, Vujaklija-Stipanovic K, Alvarez-Grande J, Schott W, Hoyer J, Schnuelle P, Descoeudres C, Ruder H, Wujciak T, Schwarz V: Prospective evaluation of pretransplant blood transfusions in cadaver kidney recipients. Transplantation 1997;63:964-967.

55 Lagaaij EL, Hennemann IP, Ruigrok M, de Haan MW, Persijn GG, Termijtelen A, Hendricks GF Weimar W, Claas FH, van Rood JJ: Effect of oneHLA-DR-antigen-matched and completely HLADR-mismatched blood transfusions on survival of heart and kidney allografts. N Engl J Med 1989;321 701-5.

56 Opelz G, Mickey MR, Terasaki PI: Identification of unresponsive kidney-transplant recipients. Lancet 1972;i:868-871.

57 Mincheff MS, Meryman HT, Kapoor V, Alsop P, Wotzel M: Blood transfusion and immunomodulation: a possible mechanism. Vox Sang 1993;65:18-24.

-58 Puppo F, Ghio M, Contini P, Mazzei C, Indiveri F: Fas, Fas ligand,and transfusion immunomodulation. Transfusion 2001;41:416-418.

59 Claas FH, de Koster HS, Lagaaij EL, van Rood JJ: A molecular mechanism of $\mathrm{T}$ cell downregulation by blood transfusion. Exp Nephrol 1993;1:134-138.

60 Waanders MM, Roelen DL, Brand A, Claas FH: The putative mechanism of the immunomodulating effect of HLA-DR shared allogeneic blood transfusions on the alloimmune response. Transfus Med Rev 2005;19:281-287.

61 Claas FH, Roelen DL, van Rood JJ, Brand A: Modulation of the alloimmune response by blood transfusions. Transfus Clin Biol 2001;8:315-317.

62 Roelen D, Brand A, Claas FH: Pretransplant blood transfusions revisited: a role for $\mathrm{CD}(4+)$ regulatory T cells? Transplantation 2004;77:S26-S28.

-63 Tartter PI, Driefuss RM, Malon AM, Heimann TM, Aufses AH: Relationship of postoperative septic complications and blood transfusions in patients with Crohn's disease. Am J Surg 1988;155:43-8.

-64 Braga M, Vignali A, Radaelli G, Gianotti L, Di Carlo V: Association between perioperative blood transfusion and postoperative infection in patients having elective operations for gastrointestinal cancer. Eur J Surg 1992;158:531-536.

65 Heiss MM, Mempel W, Jauch KW, Delanoff C, Mayer G, Mempel M, Eissner HJ, Schildberg FW: Beneficial effect of autologous blood transfusion on infectious complications after colorectal cancer surgery. Lancet 1993;342:1328-33.
66 Houbiers JG, Brand A, van de Watering LM, Hermans J, Verwey PJ, Bijnen AB, Pahlplatz P, Eeftinck SM, Wobbes T, de Vries JE: Randomised controlled trial comparing transfusion of leucocytedepleted or buffy-coat-depleted blood in surgery for colorectal cancer. Lancet 1994;344:573-578.

67 Koval KJ, Rosenberg AD, Zuckerman JD, Aharonoff GB, Skovron ML, Bernstein RL, Su E, Chakka M: Does blood transfusion increase the risk of infection after hip fracture? J Orthop Trauma 1997;11:260-5; discussion 265-6.

68 Wallis JP, Chapman CE, Orr KE, Clark SC, Forty JR: Effect of WBC reduction of transfused RBCs on postoperative infection rates in cardiac surgery. Transfusion 2002;42:1127-1134.

69 Hill GE, Frawley WH, Griffith KE, Forestner JE, Minei JP: Allogeneic blood transfusion increases the risk of postoperative bacterial infection: a meta-analysis. J Trauma 2003;54:908-914.

70 Vamvakas EC: Possible mechanisms of allogeneic blood transfusion-associated postoperative infection. Transfus Med Rev 2002;16:144-160.

71 Jensen LS, Andersen AJ, Christiansen PM, Hokland P, Juhl CO, Madsen G, Mortensen J, MollerNielsen C, Hanberg-Sorensen F, Hokland M: Postoperative infection and natural killer cell function following blood transfusion in patients undergoing elective colorectal surgery. Br J Surg 1992;79:513516

72 Blajchman MA: Allogeneic blood transfusions, immunomodulation, and postoperative bacterial infection: do we have the answers yet? Transfusion 1997;37:121-5.

73 Jensen LS, Kissmeyer-Nielsen P, Wolff B, Qvist N Randomised comparison of leucocyte-depleted ver sus buffy-coat-poor blood transfusion and complications after colorectal surgery. Lancet 1996;348: 841-5.

74 Tartter PI, Mohandas K, Azar P, Endres J, Kaplan J, Spivack M: Randomized trial comparing packed red cell blood transfusion with and without leukocyte depletion for gastrointestinal surgery. Am J Surg 1998;176:462-6.

75 Titlestad IL, Ebbesen LS, Ainsworth AP, Lillevang ST, Qvist N, Georgsen J: Leukocyte-depletion of blood components does not significantly reduce the risk of infectious complications. Results of a double-blinded, randomized study. Int J Colorectal Dis 2001;16:147-53.

76 van Hilten JA, van de Watering LM, van Bockel $\mathrm{JH}$, van de Velde CJ, Kievit J, Brand R, van den Hout WB, Geelkerken RH, Roumen RM, Wesselink RM, Koopman-van Gemert AW, Koning J, Brand A: Effects of transfusion with red cells filtered to remove leucocytes: randomised controlled trial in patients undergoing major surgery. BMJ 2004:328:1281

77 Bilgin YM, van de Watering LM, Eijsman L, Versteegh MI, Brand R, van Oers MH, Brand A: Double-blind, randomized controlled trial on the effect of leukocyte-depleted erythrocyte transfusions in cardiac valve surgery. Circulation 2004;109:27552760 .

78 Hebert PC, Fergusson D, Blajchman MA, Wells GA, Kmetic A, Coyle D, Heddle N, Germain M, Goldman M, Toye B, Schweitzer I, vanWalraven C, Devine D, Sher GD: Clinical outcomes following institution of the Canadian universal leukoreduction program for red blood cell transfusions. JAMA 2003;289:1941-9.
9 Dzik WH, Anderson JK, O’Neill EM, Assmann SF, Kalish LA, Stowell CP: A prospective, randomized clinical trial of universal WBC reduction. Transfusion 2002;42:1114-1122.

80 Llewelyn CA, Taylor RS, Todd AA, Stevens W, Murphy MF, Williamson LM: The effect of universal leukoreduction on postoperative infections and length of hospital stay in elective orthopedic and cardiac surgery. Transfusion 2004;44:489-500.

81 van de Watering L: What has universal leucodepletion given us: evidence from clinical trials? Vox Sang 2004;87(suppl 2):139-142.

82 Vamvakas EC: Transfusion-associated cancer recurrence and postoperative infection: meta-analysis of randomized, controlled clinical trials. Transfusion 1996;36:175-186.

83 Amato AC, Pescatori M: Effect of perioperative blood transfusions on recurrence of colorecta cancer: meta-analysis stratified on risk factors. Dis Colon Rectum 1998;41:570-585.

84 McAlister FA, Clark HD, Wells PS, Laupacis A: Perioperative allogeneic blood transfusion does not cause adverse sequelae in patients with cancer: a meta-analysis of unconfounded studies. Br J Surg 1998;85:171-178.

85 van de Watering LM, Brand A, Houbiers JG, Klein Kranenbarg WM, Hermans J, van de Velde C: Perioperative blood transfusions, with or without allogeneic leucocytes, relate to survival, not to cancer recurrence. Br J Surg 2001;88:267-272.

86 Burnet FM: The concept of immunological surveillance. Prog Exp Tumor Res 1970;13:1-27.

87 Maeta M, Shimizu N, Oka A, Kondo A, Yamashiro H, Tsujitani S, Ikegchi M, Kaibara N: Perioperative allogeneic blood transfusion exacerbates surgical stress-induced postoperative immunosuppression and has a negative effect on prognosis in patients with gastric cancer. J Surg Oncol 1994;55:149-53.

88 Penn I, Starzl TE: Malignant tumors arising de novo in immunosuppressed organ transplant recipients. Transplantation 1972;14:407-17.

89 Penn I: Post-transplant malignancy: the role of immunosuppression. Drug Saf 2000;23:101-13.

90 Waymack JP, Chance WT: Effect of blood transfusions on immune function: IV. Effect on tumor growth. J Surg Oncol 1988;39:159-64.

91 Shirwadkar S, Blajchman MA, Frame B, Singal DP. Effect of allogeneic blood transfusion on solid tumor growth and pulmonary metastases in mice. $\mathrm{J}$ Cancer Res Clin Oncol 1992;118:176-180.

92 Goodarzi MO, Lee TH, Pallavicini MG, Donegan EA, Busch MP: Unusual kinetics of white cell clearance in transfused mice. Transfusion 1995;35: 145-9.

93 Lee TH, Reed W, Mangawang-Montalvo L, Watson J, Busch MP: Donor WBCs can persist an transiently mediate immunologic function in a murine transfusion model: effects of irradiation, storage, and histocompatibility. Transfusion 2001; 41:637-42.

94 Hewitt HB: A critical examination of the foundations of immunotherapy for cancer. Clin Radiol 1979;30:361-9.

95 Natali PG, Bigotti A, Cavaliere R, Nicotra MR, Ferrone S: Phenotyping of lesions of melanocyte origin with monoclonal antibodies to melanoma-associated antigens and to HLA antigens. J Natl Cancer Inst 1984;73:13-24.

96 Momburg F, Degener T, Bacchus E, Moldenhauer G, Hammerling GJ, Moller P: Loss of HLA-A,B,C and de novo expression of HLA-D in colorecta cancer. Int J Cancer 1986;37:179-84. 